\title{
INTEGRATION OF THE SIMULATION AND TEST METHODOLOGIES TO DESIGN NOVEL EXHAUST MANIFOLD RIG
}

\author{
Ismail Hakki SAVCI*, Baran CELIKTEN** and Sinan EROGLU*** \\ *Ford Otosan Advanced Powertrain Department Sancaktepe, Istanbul, \\ *isavci@ ford.com.tr, ORCID: 0000-0002-7923-6061 \\ **bcelikte@ford.com.tr, ORCID: 0000-0002-3877-5237 \\ ***seroglu3@ford.com.tr, ORCID: 0000-0002-7318-2250
}

(Geliş Tarihi: 26.05.2020, Kabul Tarihi: 15.04.2021)

\begin{abstract}
Computer Aided Engineering is an effective tool utilized to drive an exhaust manifold design by early assessment within the engine program development phase. However, in the end, for exhaust manifold design verification, various tests must be performed in engine dynamometer cells under severe operating conditions. The test running durations are up to 2500 hours for the heavy-duty (HD) exhaust manifold. Therefore, the validation tests are expensive and time-consuming. Alternative ways are sought to replace these expensive tests for cost reduction purposes and more efficient dynamometer cells. Thus, the custom test rig is designed and built. This system contains the burner system supplying hot gas at a similar temperature and mass flow ranges with the engine. The drawback of the burner system is, it runs in steady-state mode, so very challenging to replicate the engine's pulsating flow effect exactly. Therefore, with the coupling of Star-CCM+ and Modefrontier, the CAE study is carried out to assess the feasibility of obtaining similar manifold skin temperature distribution in the burner test cell with engine conditions. It is aimed to determine the correct valve opening positions regulating the mass flow rate through the runners. This innovative methodology reduces the trialand-error count in the experiment phase.
\end{abstract}

Keywords: CFD, Heat Transfer, Exhaust Manifold, Testing

\section{SIMULASYON VE TEST METODOLOJILERININ YENİ EGZOZ MANIFOLDU EKIPMANI TASARLAMAK İÇIN ENTEGRASYONU}

Özet: Bilgisayar destekli simulasyon, motor geliştirme aşamasında egzoz manifoldu tasarımını için kullanılan etkin araçlardandır. Bununla birlikte, egzoz manifoldu tasarım doğrulaması için, zorlu çalışma koşulları altında motor dinamometre odalarında çeşitli testlerin gerçekleştirilmesi gerekir. Test süreleri, ağır ticari araç (HD) egzoz manifoldu için 2500 saate kadardır. Bu nedenle doğrulama testleri pahalı ve zaman alıcıdır. Maliyet düşürme amaçları ve daha verimli dinamometre kullanımı için bu pahalı testlerin yerini almanın alternatif yolları aranmaktadır. Bu amaçla, özel test donanımları tasarlanır ve inşa edilir. Bu çalışmadaki sistem, motorla benzer sıcaklık ve kütlesel debi aralıklarında sıcak gaz sağlayan brülör sistemini içerir. Brülör sisteminin dezavantajı, zamanla değişmeyen koşullarda çalışmasıdır. Bu nedenle, motorun titreşimli akış etkisini tam olarak kopyalamak çok zordur. Star-CCM + ve Modefrontier yazılımlarının birleştirilmesiyle, bilgisayar destekli mühendislik çalışması, motor koşulları ile brülör test hücresinde benzer manifold yüzey sıcaklığı dağılımı elde etmenin fizibilitesini değerlendirmek için gerçekleştirilir. Egzoz bacakları vasıtasıyla kütle debisini düzenleyen doğru vana açı pozisyonlarının belirlenmesi amaçlanır. Bu yenilikçi metodoloji, deney aşamasında deneme yanılma sayısını azaltır.

Anahtar Kelimeler: HAD, Is1 Transferi, Egzoz Manifold, Test

\section{INTRODUCTION}

In recent years, reduction of the emission level legislation and improvement of the fuel economy efficiency have become stricter for heavy-duty diesel engines in order to meet green vehicle specification (European Parliament and Council, 2009).

Exhaust manifolds are one of the crucial components of the diesel engine exhaust system. These components have a complex shape with optimum weight. Exhaust manifolds are exposed to different damage mechanisms (Assanis , 1986). These damage mechanisms are caused by two effects: vibrational loadings related to high cycle fatigue or thermal loadings related to low cycle fatigue (Simone, 2014) (Benoit, 2012). The studies of exhaust manifold are performed for the thermal performance of the exhaust manifold itself and complete engine durability. Concerning this, some investigations have focused on the development of exhaust manifold design (Ekstrem, 2014) 
(Ho, 1972) (Byung Kyu, 2013). Exhaust manifold design should not only be more durable to limit the effect of the high-temperature loading but also supportive in terms of fuel consumption efficiency (Heywood, 1988) (Annand, 1963).

During the engine operation, the exhaust manifold is subjected to severe thermal cycling under harsh operating conditions. These conditions are the result of in-cylinder combustion, which also shows time-varying behavior ( Meda, Shu Y., \& Meda, 2012). These cycling thermal load conditions cause thermal fatigue failure, such as cracking of the exhaust manifold. Low cycle fatigue failures are directly related to thermal cycles (Belingiardi \& Leonti, 1987). Several researchers have asserted the importance of damage effects of the thermal loading on the exhaust manifold (Charkaluk, Bignonnet, Constantinescu , \& Dang Van, 2002). High cycle fatigue failures of the exhaust manifold from vibrational loadings are discretized in the literature (Wolff, Schneider, \& Schernus, 1988).

Many studies were conducted with the motivation for developing a deeper understanding of heat transfer behavior. Some of them are based on simple thermal resistance models. Some others are focused on developing analysis methods for better heat transfer behavior prediction (Cartwright, Selamet, Wade, Miazgowicz, \& Sloss, 2015) (Chen, Wang, Wu, \& Xin, 2014) (Zhien, Wang, Yan, Li, \& Xu, 2014). In recent years, with the increasing use of computational fluid dynamics modeling, many studies are focused on predicting the thermal behavior of the system.

The complexity of fatigue resistance in the exhaust manifold is very complicated since the relevant phenomena are transient. Hence, three-dimension and many aspects have to be taken into consideration (Zhien, Wang, Yan, Li, \& Xu, 2014) (Hasse , Sohm, \& Durst, 2010). Therefore, coming up with a robust and durable manifold design is a critical and challenging task. The development of an exhaust manifold requires advanced and robust CAE methods in the early stages of the design process-long-running design verification tests in dynamometer testing cells, which are very expensive and time-consuming. (Demirkesen, Colak, Savci, \& Zeren, 2020)A low-cost test solution such as a special exhaust manifold rig is recommended to meet the correlation requirement for $\mathrm{CAE}$ and test for life prediction.

The main goal of this study is to build and validate an innovative experimental exhaust manifold thermal test setup. Test setup can perform reliable studies for predicting the heat transfer behavior of the exhaust manifold. In order to accomplish this, a well-controlled bench was built that reproduces exhaust manifold operating conditions. Also, the test setup is equipped with a robust measurement system, including fast response thermocouples for instantaneous temperature measurement simultaneously.
The authors have already reported detailed thermodynamics and heat transfer behavior of the exhaust manifold. The transient thermal analysis assessment of the 91t I6 HD engine exhaust manifold is presented. The paper consists of three main parts; the first part presents the CFD studies conducted for the temperature correlation of exhaust manifold, the second part explains the custom exhaust manifold experimental rig built to reach similar thermal load results as the exhaust manifold test result in dynamometer and the third section covers the details of determining the representative mass flow rates through each runner of exhaust manifold as in the experimental test setup. (Savci \& Zeren, 2019)

The ability to accurately predict the metal temperature of the exhaust manifold is essential for a robust and durable design because the temperature distribution is the critical input for life prediction analysis carried out using finite element software. This paper detailed thermal modeling of exhaust manifold underrated power engine operating condition of Ford Otosan's I6 91t HD Ecotorq diesel engine (see Figure 1) using 3D CFD, is reported. TC1, located at the neck area where two sides of the manifold are combined (behind TC9), and other TCs represent the thermocouples and locations on the exhaust manifold.

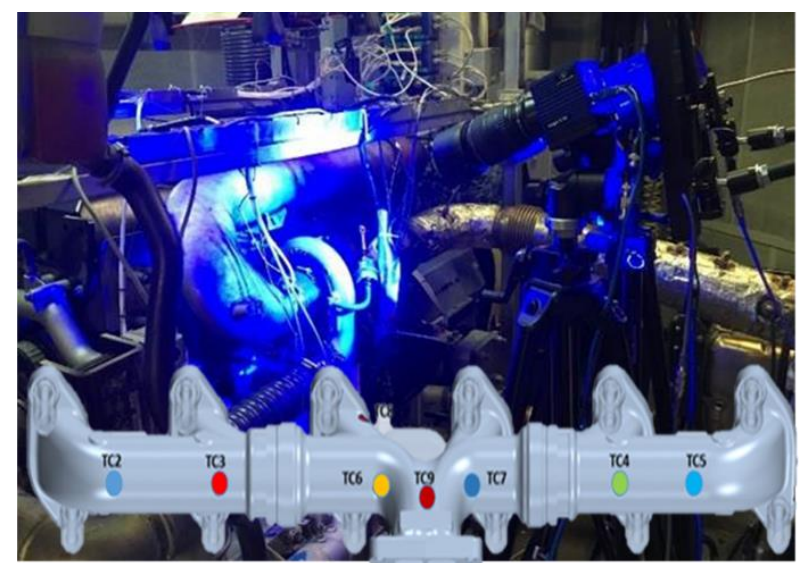

Figure 1. Dynamometer test cell

Initially, the temperature distribution of the exhaust manifold is measured at the dynamometer test cell with instrumented thermocouples and thermal cameras. Measured temperature values, shown in Figure 2, are used to correlate the CFD predictions with the test bench measurements. These measured temperatures show stabilized metal temperatures when the engine is running at a particular operating point. To prevent misunderstanding, it can be explained again, gas can have pulsating (transient) behavior, but the effect of gas on the metal is going to be stabilized if the engine runs sufficiently long time at that certain operating point. 


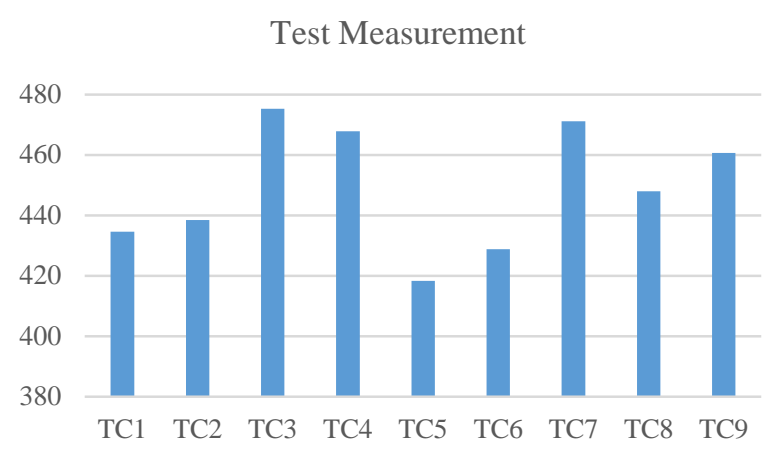

Figure 2. Dynamometer temperature test results for exhaust manifold

\section{NUMERICAL MODELS}

\section{Co-Simulation Model}

The co-simulation method is used to run different CAE models containing different connected domains. The process of the co-simulation study for the exhaust manifold is shown in Figure 3. To solve the fluid domain, minimal time steps around the range of 1 degree crank angle have to be specified due to the crank angle-based flow variation and pulsation within the domain. However, the response of manifold metal itself is not that fast. Therefore, the solid domain does not either require a minimal time step size nor a large number of inner iterations for each time step. With the co-simulation feature of CFD code, exhaust gas domain and exhaust manifold solid domain are modeled separately with different time step sizes and number of inner iteration numbers. For the cases such as exhaust manifold, where the time scales of the thermal conduction in the solid are much longer than the time scales in the fluid, STAR$\mathrm{CCM}+$ to STAR-CCM+ co-simulation offers a particular advantage (STAR-CCM+, 2019).

In literature, co-simulation is also named super-cycling for different CFD codes. The method is the same, fluid flows, which have cyclic behavior as in four stoke engine, have to be modeled based on crank angle. Because boundary conditions are all crank angle based. Nevertheless, metal surfaces used only near-wall gas temperature, and the heat transfer coefficient for convection heat transfer do not have to run with the same timescales. Moreover, metal timescales have to be much more to see the effect on the temperature distribution change in shorter solution times. This distribution is used as the fluid wall temperature boundary condition, an effective near-wall gas temperature. With numerous repeating and cyclic behavior of flow, metal temperatures, gas near-wall temperature, and heat transfer coefficient converge.

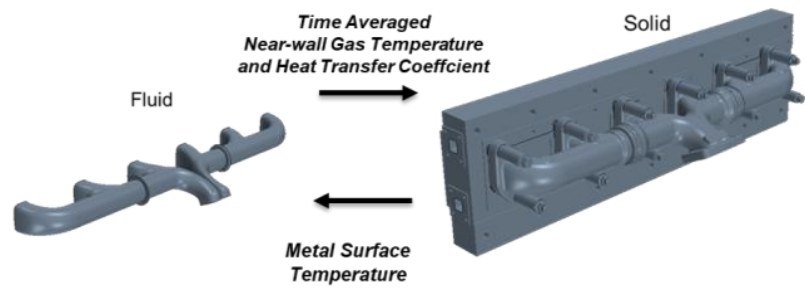

Figure 3. Co-simulation scheme

The boundary conditions of fluid domain co-simulation analysis are supplied by the 1D engine performance system model with 1-degree crank angle-resolved. GTPower software is used for 1D performance modeling. Once the correlation is achieved with a dyno, the mass flow rates, temperatures, and pressures are extracted for each of six cylinders for desired engine operating conditions (inlets and outlets of the manifold). The tables containing the boundary condition data are generated in GT-Power in a format that can be directly read by the CFD model. Manifold inlet ports are defined as mass flow inlet, and outlet ports are defined as pressure outlets in the fluid model. From the CFD point of view, since the most timeconsuming part of this study is the computational run times of the CFD models, several CFD runs were carried out to develop optimum element size and time step combination to assure convergence each time step (Yanarocak, Ergenc, \& Duman, 2016). The co-simulation CFD model contains about 260k trim elements, and the time step is defined as 0.5-degree crank angle. A mesh sensitivity study was carried out with a model containing about 400k cells, pointing out negligible effect on the results (Celikten, Duman, Harman, \& Eroglu, 2018). With this mesh setting, $y+$ values are calculated at every time step, and the mean of $y+$ values is shown in Figure 4.

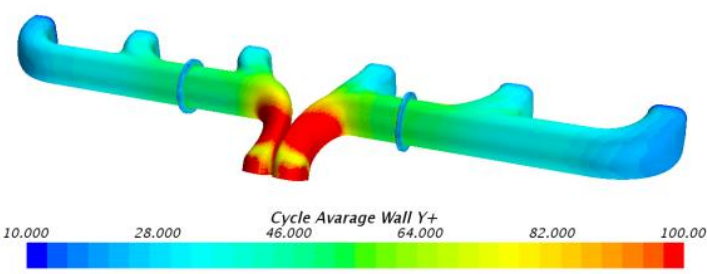

Figure 4. Cycle average y+ contour

In STAR-CCM+, the conceptual centerpiece for modeling convective heat transfer at the wall for turbulent flows stems from the standard wall functions. The formulation is below where;

- $\quad \rho_{f}$ is the fluid density

- $C_{p, f}$ is the fluid-specific heat capacity.

- $u^{*}$ is a reference velocity.

- $T^{+}$is the dimensionless temperature.

- $y^{+}$is the dimensionless wall distance.

- $y_{c}$ and $T_{C}$ are the normal distance and temperature of the near-wall cell, respectively.

$$
q_{s}^{\prime \prime}=\frac{\rho_{f}\left(y_{c}\right) C_{p, f}\left(y_{c}\right) u^{*}}{T^{+}\left(y^{+}\left(y_{c}\right)\right)}\left(T_{s}-T_{C}\right)
$$


For coupling cases like co-simulation, Star-CCM+ offers different heat transfer coefficients and gas temperature calculation, called specified $y+$ heat transfer coefficient and specified $y+$ reference temperature. Specified $y+$ heat transfer coefficient and reference temperature calculation are below where;

- $\quad h_{2}$ is specified $\mathrm{y}+$ heat transfer coefficient

- $T_{r e f, 2}$ is specified $\mathrm{y}+$ reference temperature

- $y_{u s e r}^{+}$is user-defined wall y+

$$
\begin{gathered}
h_{2}=\frac{\rho_{f}\left(y_{c}\right) C_{p, f}\left(y_{c}\right) u^{*}}{T^{+}\left(y_{u s e r}^{+}\right)} \\
T_{\text {ref }, 2}=T_{s}-\frac{q_{s}^{\prime \prime}}{h_{2}}
\end{gathered}
$$

This heat transfer coefficient and reference temperature pair are less dependent than other methods. The userspecified value of $\mathrm{y}+$ should be less than approximately 150. A value of 100 has been shown to work well (STAR$\mathrm{CCM}+, 2019)$.

To measure the skin temperature on the manifold, several thermocouples were used in dynamometer tests. In the CFD model, monitored points are created at thermocouple locations, and temperatures are compared with test results. To avoid the adverse effect of poor cells in CFD, thermocouples are not modeled physically; just patches are created on the exhaust manifold, and their temperatures are monitored.

Table 1. Co-simulation physics Fluid Domain Physics Settings

\begin{tabular}{lc}
\hline \multicolumn{2}{c}{ Fluid Domain Physics Settings } \\
\hline Time Dependence & Transient \\
Time Step [Crank Angle] & $0.5(4.63 \mathrm{e}-05 \mathrm{~s})$ \\
Solution Time [Crank Angle] & $28800(40$ engine cycle $)$ \\
Turbulence Model & K-Epsilon Turbulence Model \\
Temperature Dependence & Segregated Flow 2nd Order \\
Wall Treatment & Two Layer All y+ \\
Density Definition & Ideal Gas \\
Viscosity & Sutherland's Law \\
Data Exchange Duration [Crank & 2.5 \\
Angle] & 15 \\
Inner Iteration for 1 time-step & Lead \\
Co-simulation Concurrency Mode & \\
\hline \hline & Solid Domain Physics Settings \\
\hline Time Dependence & Transient \\
Time Step [s] & 0.01 \\
Solution Time [s] & 600 \\
Temperature Dependence & Segregated Solid Energy \\
Density Definition & Constant \\
Data Exchange Time [s] & 0.052 (solution time/ total \\
Inner Iteration for 1 time-step & data exchange count) \\
Co-simulation Concurrency Mode & 5 \\
& Lag
\end{tabular}

In co-simulation methodology, the modeling of the fluid domain takes the exhaust gas pulsation effect into account. So the fluid and solid models are run transient. Table 1 shows the physics settings for analysis. For both fluid and solid simulations, the total data exchange count is the same. In other words, they run in synchrony. The Timesteps of simulations depend on the data exchange times.
They are one-fifth of data exchange time, which means both simulations run five-time steps before sharing data with each other.

\section{Co-simulation Results}

The temperature distribution obtained from the cosimulation analysis is shown in Figure 5. The fluid model is run for 40 engine cycles, and the exhaust manifold solid is run for 600 seconds by exchanging data at specific intervals. All residuals and temperature variations have reached a steady state. The scalar function in Figure 5 (TransientTemp) represents the stabilized temperature of the time-dependent (Co-simulation) simulation. It is called that to perceive the difference between a steady-state (time-independent) case.

\section{DESIGN OF THE EXPERIMENTAL EXHAUST MANIFOLD TEST SETUP}

Dynamometer design verification tests last around 600 hours for only one calibration level. This is not an efficient process due to high fuel consumption. Therefore, an alternative way is sought for design verification of the exhaust manifold, and a custom dedicated test rig was designed and experimented with. There are several advantages of the rig when compared to the dynamometer tests. The main ones are as follows;

- Cost (Using natural gas instead of diesel fuel)

- Easy installation and less complexity (Only manifold changes instead of the entire engine)

- Time advantages of tests rigs over dynamometer tests

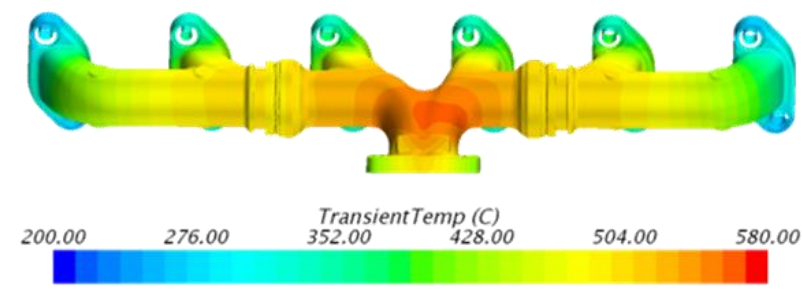

\begin{tabular}{|c|c|c|c|}
\cline { 2 - 4 } \multicolumn{1}{c|}{} & Dyno [C] & Co-Simulation [C] & Difference $\%$ \\
\hline TC1 & 435 & 443 & $2 \%$ \\
\hline TC2 & 439 & 428 & $-3 \%$ \\
\hline TC3 & 475 & 471 & $-1 \%$ \\
\hline TC4 & 468 & 461 & $-1 \%$ \\
\hline TC5 & 418 & 405 & $-3 \%$ \\
\hline TC6 & 429 & 425 & $-1 \%$ \\
\hline TC7 & 471 & 469 & $0 \%$ \\
\hline TC8 & 448 & 428 & $-4 \%$ \\
\hline TC9 & 461 & 473 & $3 \%$ \\
\hline
\end{tabular}

Figure 5. Co-simulation manifold temperatures

The exhaust manifold test rig is helpful to simulate exhaust manifold temperatures as in real engine conditions. A gas burner is used for heating the gas and discharge the steady-state gas to the rig through one main port. However, in the real world, engine cylinders have 
different combustion timing, and there is pulsating flow in the exhaust ports. The most challenging point of using a rig is to obtain the optimum gas mass flow rate and temperature that the burner supplies. Temperature distribution, which is obtained from engine pulsating flow, is mimicked by the steady-state flow supplied by the burner. This is challenging; therefore, the mass flow rates through each runner are regulated by the integrated mechanical valves (See Figure 6). Trial and error cannot meet comparable temperatures on the exhaust manifold with the test in a reasonable time. Therefore, to determine the total mass flow rate, gas temperature, and valve openings, the CFD study should be carried outs.

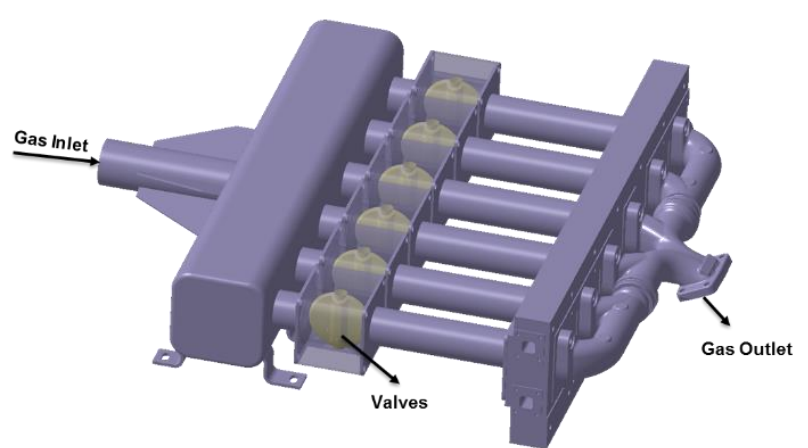

Figure 6. Thermal manifold rig

\section{Adjusting Valves for Necessary Flowrate}

The hot gas burner in the test cell provides a steady gas mass flow rate and temperature. To mimic the real-life temperature distribution of the exhaust manifold, the amount of the gas flow passing through each runner has to be adjusted using the valves located at the entrance of each runner within the system. The results of exhaust manifold temperature distribution obtained by the using $\mathrm{Co}-$ simulation method, explained in the previous section, were used for the targeted distribution.

The CFD model of the custom test rig was built to determine the mass flow rates through each runner. However, calculating the mass flow rate distribution between runners by employing a trial and error approach is cumbersome. So on optimization tool, Modefrontier, was used and coupled with steady-state CFD models, in order to come up with correct valve opening positions. Modefrontier uses its algorithms. The total mass flow rate and temperature of gas supplied by the burner were defined as input variables. The adjusting process was handled in two steps, mainly due to reducing the computational run time. Because of that, the model was coupled with two separate CFD models.

Optimized CFD simulations are based on steady-state flow test results. Physics settings of the steady-state simulation are shown in Table 2.

\section{I.1. The First Step}

The first adjusting step was carried out to calculate the required mass flow rate through each runner. The model built in Star-CCM+, as seen in Figure 6, does not contain the valves and the upstream gas chamber. So the objective in the first step is to minimize the temperature difference between the CFD model (seen in Figure 7) and the results obtained from the Co-simulation model, whose results are well correlated with dynamometer measurements (Figure 5). To monitor the temperature, small patches at the thermocouple measurement locations are created on the ambient surface of the exhaust manifold of the CFD model in which R1 to R6 represents the runner alignment on the engine.

Table 2. Steady state CFD simulation physics

\begin{tabular}{lc}
\hline \hline \multicolumn{2}{c}{ General Settings } \\
\hline Time Dependence & Steady State \\
\multicolumn{1}{c}{ Maximum Iteration } & F.00E+03 \\
& Fluid Domain Physics Settings \\
\hline Turbulence Model & K-Epsilon Turbulence Model \\
Temperature Dependence & Segregated Flow 2nd Order \\
Wall Treatment & Two Layer All y+ \\
Density Definition & Ideal Gas \\
Viscosity & Sutherland's Law \\
\hline \hline \multicolumn{2}{c}{ Solid Domain Physics Settings } \\
\hline \multicolumn{2}{l}{ Temperature Dependence } \\
Density Definition & Segregated Solid Energy \\
& Constant
\end{tabular}

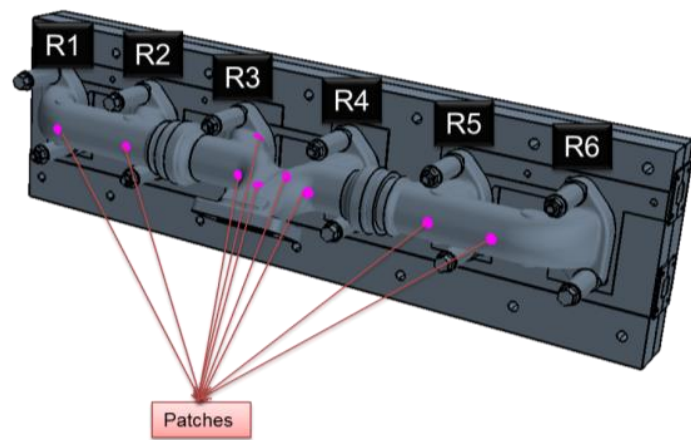

Figure 7. First step CFD model

In the Modefrontier model, the SIMPLEX algorithm is used to find the required mass flow rates for each exhaust manifold runner. The variables of total mass flow rate, temperature, and each runner mass flow percentages are defined as input variables and aimed to determine the software's output. Due to the symmetry of the exhaust manifold, symmetric runners are expected to have similar flow rates. This symmetry helps the number of variables to be reduced by half. As can be seen in Figure 7, input variables Runner_Percentage_1 and Runner_Percentage_2 are created for Runner1 \& Runner6 and Runner2 \& Runner5 respectively. Runner3 \& Runner 4 flow rates are dependent variables. In other words, Runner3 and Runner4 flow rates are automatically determined with an equation, as can be seen in the equation.

$$
\dot{m}_{R 3}=\dot{m}_{R 4}=\frac{\dot{m}_{\text {Total }}-\left[\left(\dot{m}_{R 1}+\dot{m}_{R 6}\right)+\left(\dot{m}_{R 2}+\dot{m}_{R 5}\right)\right]}{2}
$$




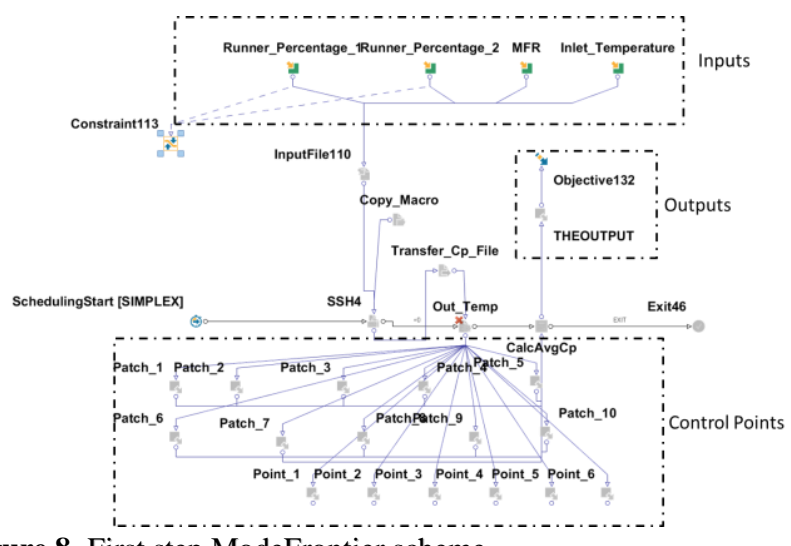

Figure 8. First step ModeFrontier scheme

In Figure 8, the DoE sequence is specified, which has to be one higher than the total input variable number for the SIMPLEX algorithm to understand the effect of each one of the input variables. With a couple of in-house developed user codes, CFD analyses are performed in order. The genetic algorithm learns the effect of every step of input variable changes. It evaluates the input variables to reach the objective. The objective is to minimize the value of the "THEOUTPUT" parameter (Eq.13), which is the absolute temperature difference of CFD predictions on the patches and thermocouple measurements. The main reason for taking absolute values of difference is to avoid negative differences. If the difference were not selected as absolute, THEOUTPUT value would be directed to negative infinity. THEOUTPUT and objective functions can be seen in the equations below.

$$
\begin{gathered}
\text { THEOUTPUT }=\sum_{i=1}^{10} \operatorname{abs}\left(T_{\text {TEST_Patch } \_}-T_{\text {CFD_Patch } \__{-}}\right) \\
\text {Objective }=\min (\text { THEOUTPUT })
\end{gathered}
$$

After 26 iterations, the generic algorithm found the mass flow rate percentages through each runner to minimize the objective value. The convergence is shown in Figure 9, and the results are shown in Table 3.

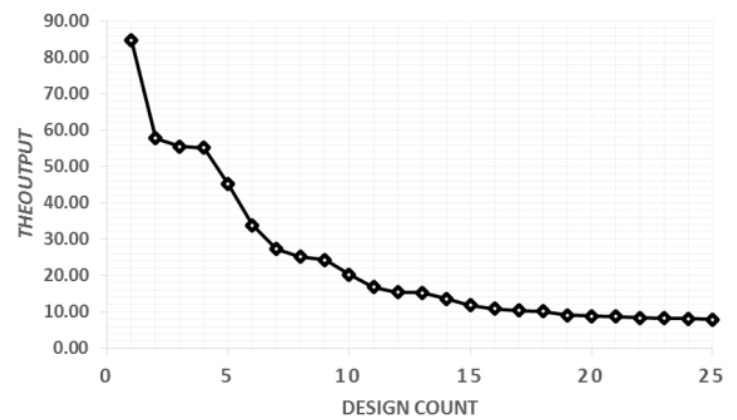

Figure 9. First step convergence

\section{The Second Step}

The second step was conducted to determine the correct valve opening positions, meeting the mass flow rates obtained from the previous step. CFD model used in the second step is seen in Figure 10. So the objective in the second step is to minimize the mass flow difference with the results obtained from the first step. Every valve position is changed with the specific coordinate system along the z-direction. Therefore input variables are angles that valves are rotated. For this step, due to the symmetry nature of the model, three input variables are used in the previous model. Modefrontier set up is shown in Figure 11. RP1 to RP6 represent the runner flow rate percentages, and "THEOUTPUT_2" represents the absolute differences of the mass flow rates from the targeted flow rate.

\begin{tabular}{|c|c|c|c|c|c|c|}
\hline Design No & $\begin{array}{l}\text { Inlet } \\
\text { Temperature } \\
\text { (K) }\end{array}$ & $\begin{array}{l}\text { Total } \\
\text { Mass } \\
\text { Flowrate } \\
(\mathrm{kg} / \mathrm{h})\end{array}$ & $\begin{array}{l}\text { R1-R6 Mass } \\
\text { Flowrate } \\
\text { Percentage }\end{array}$ & $\begin{array}{l}\text { R2-R5 Mass } \\
\text { Flowrate } \\
\text { Percentage }\end{array}$ & $\begin{array}{l}\text { R3-R4 Mass } \\
\text { Flowrate } \\
\text { Percentage }\end{array}$ & OUTPUT \\
\hline 1 & 973.15 & 650 & $17 \%$ & $26 \%$ & $7 \%$ & 84.65 \\
\hline 2 & 923.15 & 700 & $5 \%$ & $39 \%$ & $7 \%$ & 57.72 \\
\hline 3 & 973.15 & 650 & $31 \%$ & $4 \%$ & $16 \%$ & 55.49 \\
\hline 4 & 923.15 & 700 & $5 \%$ & $39 \%$ & $7 \%$ & 55.18 \\
\hline 5 & 923.15 & 700 & $7 \%$ & $30 \%$ & $13 \%$ & 45.15 \\
\hline 6 & 973.15 & 650 & $35 \%$ & $5 \%$ & $11 \%$ & 33.86 \\
\hline 7 & 923.15 & 700 & $31 \%$ & $12 \%$ & $8 \%$ & 27.33 \\
\hline 8 & 923.15 & 700 & $11 \%$ & $30 \%$ & $9 \%$ & 25.09 \\
\hline 9 & 923.15 & 700 & $12 \%$ & $23 \%$ & $15 \%$ & 24.28 \\
\hline 10 & 923.15 & 700 & $26 \%$ & $16 \%$ & $9 \%$ & 20.30 \\
\hline 11 & 923.15 & 700 & $24 \%$ & $19 \%$ & $7 \%$ & 16.76 \\
\hline 12 & 923.15 & 700 & $14 \%$ & $28 \%$ & $8 \%$ & 15.38 \\
\hline 13 & 923.15 & 700 & $15 \%$ & $25 \%$ & $11 \%$ & 15.24 \\
\hline 14 & 923.15 & 700 & $22 \%$ & $21 \%$ & $8 \%$ & 13.54 \\
\hline 15 & 923.15 & 700 & $21 \%$ & $23 \%$ & $7 \%$ & 11.85 \\
\hline 16 & 923.15 & 700 & $16 \%$ & $27 \%$ & $8 \%$ & 10.86 \\
\hline 17 & 923.15 & 700 & $20 \%$ & $24 \%$ & $7 \%$ & 10.35 \\
\hline 18 & 923.15 & 700 & $16 \%$ & $26 \%$ & $9 \%$ & 10.14 \\
\hline 19 & 923.15 & 700 & $19 \%$ & $25 \%$ & $7 \%$ & 9.09 \\
\hline 20 & 923.15 & 700 & $18 \%$ & $25 \%$ & $7 \%$ & 8.79 \\
\hline 21 & 923.15 & 700 & $17 \%$ & $26 \%$ & $8 \%$ & 8.74 \\
\hline 22 & 923.15 & 700 & $17 \%$ & $27 \%$ & $7 \%$ & 8.34 \\
\hline 23 & 923.15 & 700 & $18 \%$ & $26 \%$ & $7 \%$ & 8.28 \\
\hline 24 & 923.15 & 700 & $18 \%$ & $26 \%$ & $7 \%$ & 8.11 \\
\hline 25 & 923.15 & 700 & $17 \%$ & $27 \%$ & $7 \%$ & 7.89 \\
\hline 26 & 923.15 & 700 & $18 \%$ & $27 \%$ & $6 \%$ & 7.58 \\
\hline
\end{tabular}

Table 3. First step results

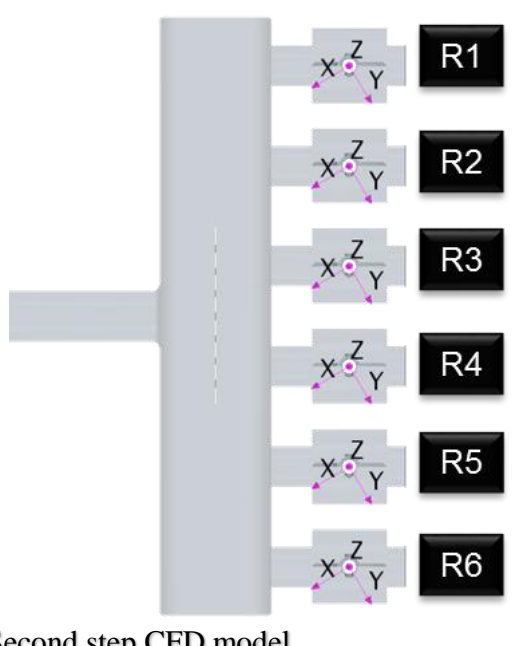

Figure 10. Second step CFD model 
Valve openings are the main variables affecting flowrate through the runners. If the valve closes the section too much, the flow tends to an easier route, and the flow rate is lower than the other runners.

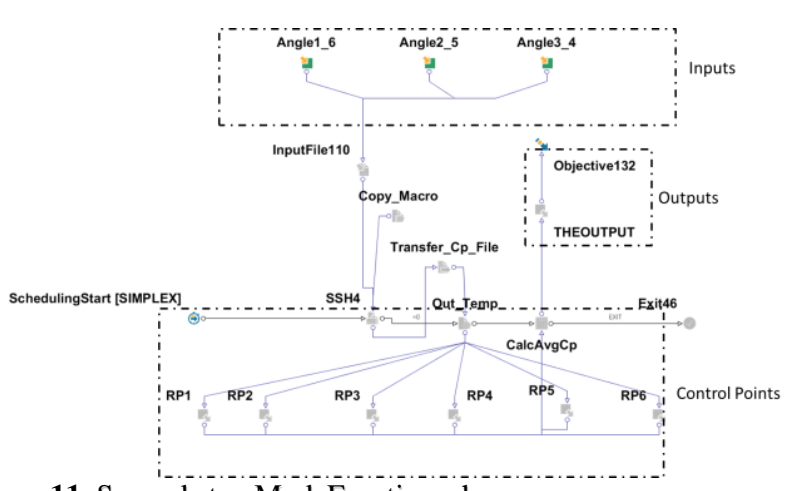

Figure 11. Second step ModeFrontier scheme

$$
\begin{aligned}
\text { THEOUTPUT_2 } & =\sum_{i=1}^{6} \operatorname{abs}\left(\dot{m}_{\text {Required }, i}-\dot{m}_{\text {case }, i}\right) \\
\text { Objective } & =\min (\text { THEOUTPUT_2 })
\end{aligned}
$$

"THEOUTPUT_2" and objective functions can be seen in Equations 4 and 5. After 17 generations, the genetic algorithm found the angles that the valves should be set. The convergence is shown in Figure 12, and the results of the second step are shown in Table 4. The final position of valves is shown in Figure 13.

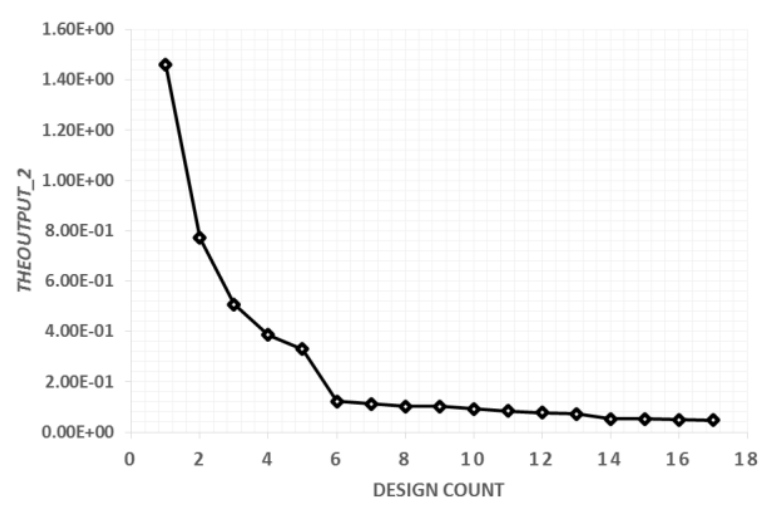

Figure 12. Second step convergence

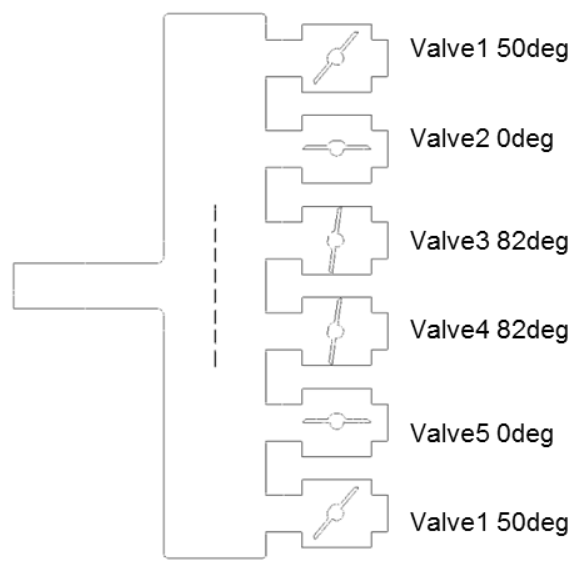

Figure 13. Optimized valve positions
Table 4. Second step results

\begin{tabular}{ccccc}
\hline \hline Design No & Angle 1-6 & Angle 2-5 & Angle 3-4 & THEOUTPUT_2 \\
\hline \hline 1 & 53 & 1 & 80 & $1.46 \mathrm{E}+00$ \\
\hline \hline 2 & 49 & 1 & 80 & $7.72 \mathrm{E}-01$ \\
\hline \hline 4 & 57 & 7 & 66 & $5.07 \mathrm{E}-01$ \\
\hline \hline 5 & 52 & 2 & 77 & $3.87 \mathrm{E}-01$ \\
\hline \hline 6 & 51 & 8 & 71 & $3.29 \mathrm{E}-01$ \\
\hline \hline 7 & 52 & 1 & 77 & $1.22 \mathrm{E}-01$ \\
\hline \hline 8 & 45 & 6 & 78 & $1.13 \mathrm{E}-01$ \\
\hline \hline 9 & 45 & 3 & 85 & $1.02 \mathrm{E}-01$ \\
\hline \hline 10 & 45 & 0 & 85 & $1.02 \mathrm{E}-01$ \\
\hline \hline 11 & 48 & 0 & 85 & $9.19 \mathrm{E}-02$ \\
\hline \hline 12 & 47 & 0 & 84 & $8.45 \mathrm{E}-02$ \\
\hline \hline 13 & 49 & 1 & 84 & $7.76 \mathrm{E}-02$ \\
\hline \hline 14 & 49 & 1 & 79 & $7.27 \mathrm{E}-02$ \\
\hline \hline 16 & 48 & 1 & 80 & $5.28 \mathrm{E}-02$ \\
\hline \hline 17 & 49 & 1 & 82 & $5.16 \mathrm{E}-02$ \\
\hline \hline & 50 & 0 & 82 & $4.84 \mathrm{E}-02$ \\
\hline \hline
\end{tabular}

Finally, with the valve openings obtained, the entire model was run, and temperature distribution was compared with the results obtained from the co-simulation model. Good agreement was achieved within the range of $0-4 \%$ for all patches (Figure 14). Steady-state exhaust manifold CFD temperatures are shown in Figure 15. The close similarity of the results is observed with the co-simulation model.

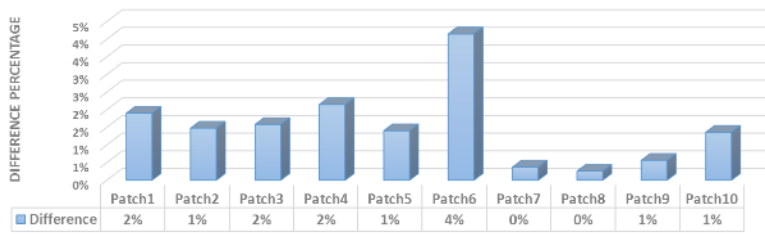

Figure 14. Difference between co-simulation and steady-state CFD models

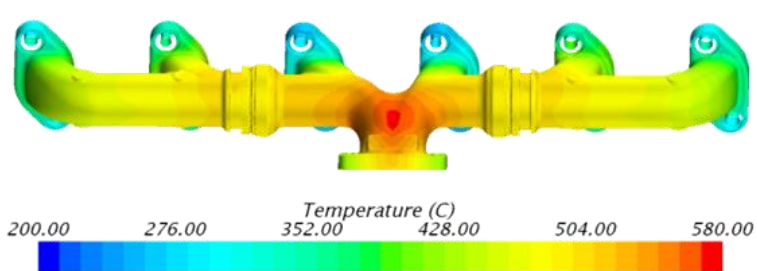

Figure 15. Steady state manifold temperatures

\section{RESULTS OF THE EXPERIMENTAL EXHAUST MANIFOLD TEST SETUP}

An exhaust manifold test rig is developed to evaluate the (thermal) low cycle fatigue life by mimicking an engine dyno test. The test rig has two main advantages over the dynamometer. The first one is; design validation tests in the test rig are only explicitly performed for the exhaust manifold itself with less complexity and eliminate all noise factors caused by the dynamometer. The second one is, the cost of design validation of exhaust manifold is reduced.

The exhaust manifold test setup is shown in Figure 16. The 
gas burner is used to supply the exhaust mass flow and temperature at desired values. The main components of the test setup are; distribution channel, butterfly valves (EGR valves used in the engine), cooling jacket, and exhaust manifold.

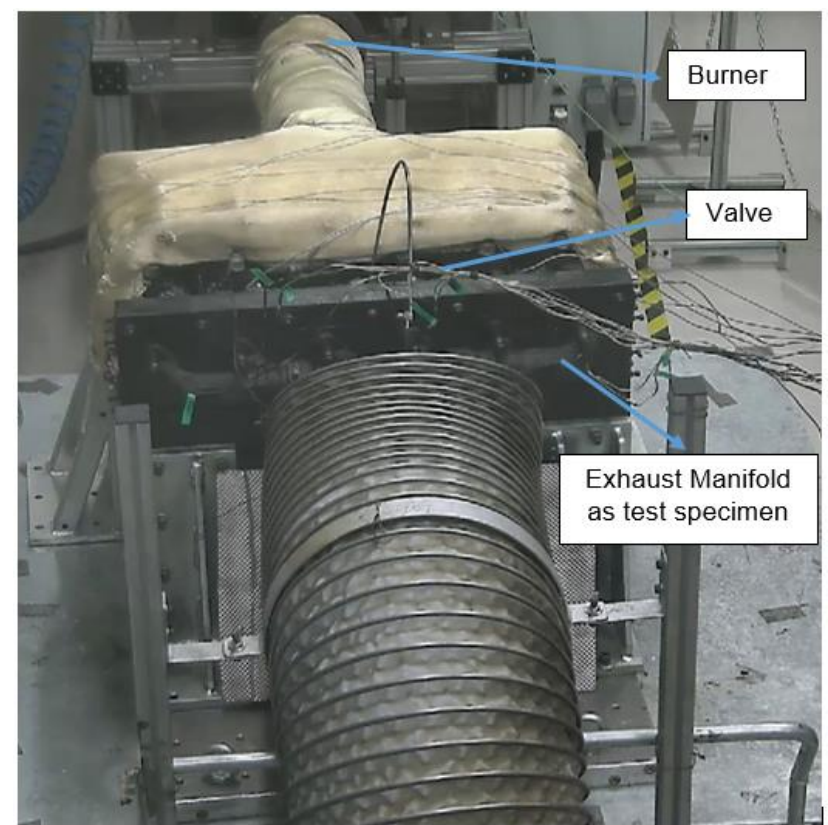

Figure 16. Custom exhaust manifold test rig with the burner

Each valve's angle position can be set manually. Figure 17 shows the valves in the exhaust manifold test setup. EGR valves are used to replicate the engine flow characteristics of the exhaust manifold in the dynamometer.

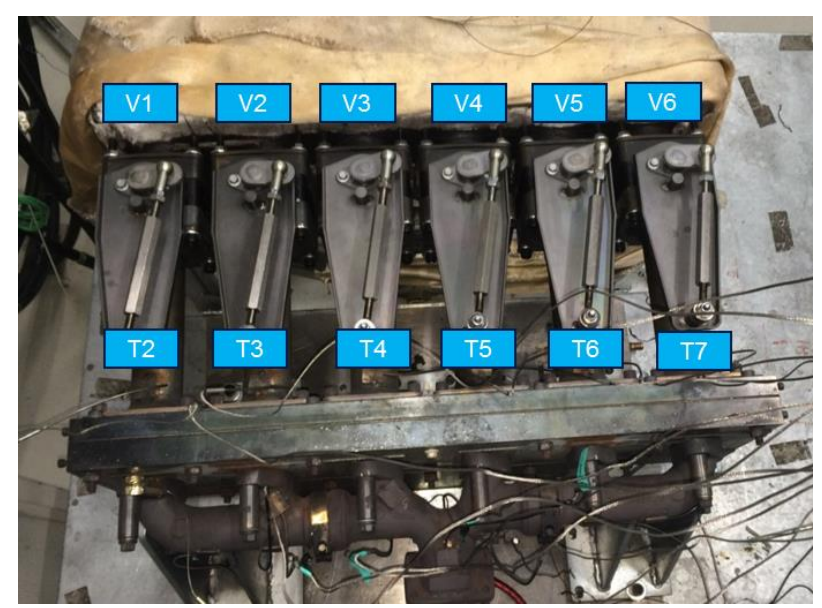

Figure 17. Exhaust manifold test rig with EGR valves

The critical requirement for the fatigue life test is to ensure that the temperature distribution of the exhaust manifold in the test rig is in a similar range as in the real engine under specific operating loads. Data is collected from the thermocouples, shown in figure 18, under steady conditions and then time-averaged. The angular positions of each valve must be set accordingly to mimic the real engine exhaust manifold temperature ranges.

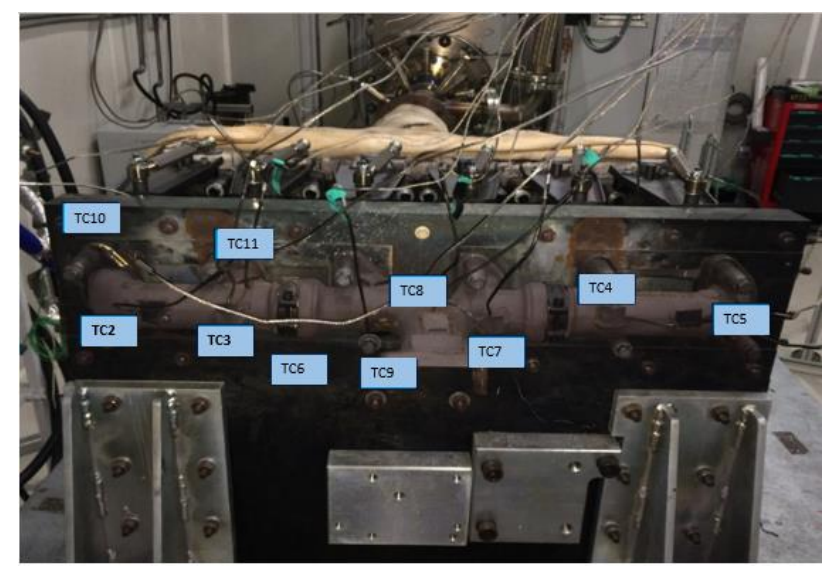

Figure 18. Exhaust manifold test rig with EGR valves

16 different valve angular position combinations are experimented with manually to correlate the test results of the exhaust manifold with the test results of the dynamometer.

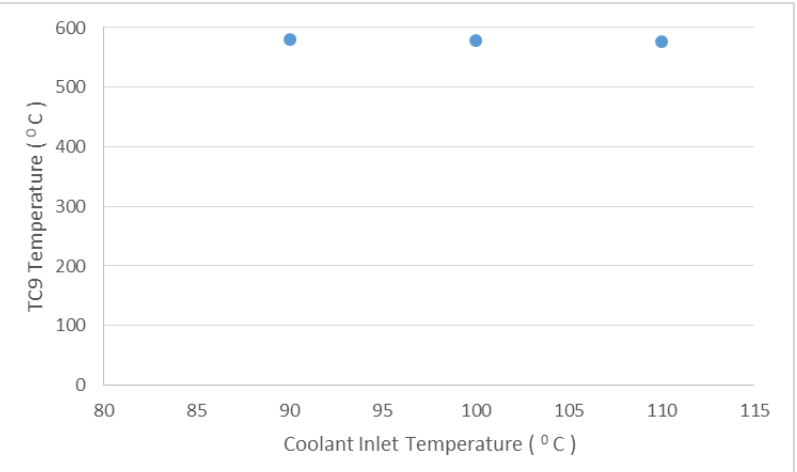

Figure 19. Effect of the coolant inlet temperature on the midpoint of the exhaust manifold

Coolant inlet temperature tests were performed to understand the coolant inlet temperature effect on the exhaust manifold's temperature distribution. Figure 19 shows that the manifold heat rejection rate is relatively insensitive to changes in the coolant flow rate.

The specified angular positions of the EGR valves set are shown in Table 5. Valve position from CFD also experimented as the proposed methodology.

Figure 20 shows the temperature differences of the dynamometer and test setup at the thermocouple location for different valve angles. T9 thermocouple is the central position of the exhaust manifold. This point is the most critical point for dynamometer and test setup comparison. Three thermocouples are located at the left bank of the exhaust manifold, and three thermocouples are at the right side of the exhaust manifold. The results of the thermocouples in the test setup should be comparable with dynamometer results. 
Table 5. Test set point for the EGR valve angle

\begin{tabular}{cccccccc}
\hline \hline Set & $\begin{array}{l}\text { Valve } \\
\# 1\end{array}$ & $\begin{array}{l}\text { Valve } \\
\# 2\end{array}$ & $\begin{array}{l}\text { Valve } \\
\# 3\end{array}$ & $\begin{array}{l}\text { Valve } \\
\# 4\end{array}$ & $\begin{array}{l}\text { Valve } \\
\# 5\end{array}$ & $\begin{array}{l}\text { Valve } \\
\# 6\end{array}$ & Method \\
\hline \hline 1 & 90 & 90 & 90 & 90 & 90 & 90 & Iterative \\
\hline \hline 2 & 85 & 90 & 57 & 57 & 90 & 85 & Iterative \\
\hline \hline 3 & 80 & 90 & 90 & 90 & 90 & 80 & Iterative \\
\hline \hline 4 & 60 & 90 & 8 & 8 & 90 & 40 & CFD \\
\hline \hline 5 & 30 & 90 & 8 & 8 & 90 & 30 & Iterative \\
\hline \hline 6 & 40 & 70 & 8 & 8 & 70 & 40 & Iterative \\
\hline \hline
\end{tabular}

In figure 20, the $\mathrm{X}$-axis shows the ID number of the different valve sets. The $\mathrm{Y}$-axis shows the temperature difference results for each thermocouple as the bar column. The green dot shows the average temperature differences of all thermocouples with dynamometer results for each valve setting. The test rig tends to underpredict temperature results.

Each run for each valve set configuration takes about 2 hours. After 16 manual iterations for different valve openings, temperature variation decreased to 10 degree $\mathrm{C}$, such as valve set 5 and valve set 6 configurations. Only for one operating condition, this trial-and-error approach required 16 experiments to be conducted. In addition to that, the design validation of the manifold test has to be conducted under several different operating conditions. So, this traditional method is time-consuming, expensive, and not robust.

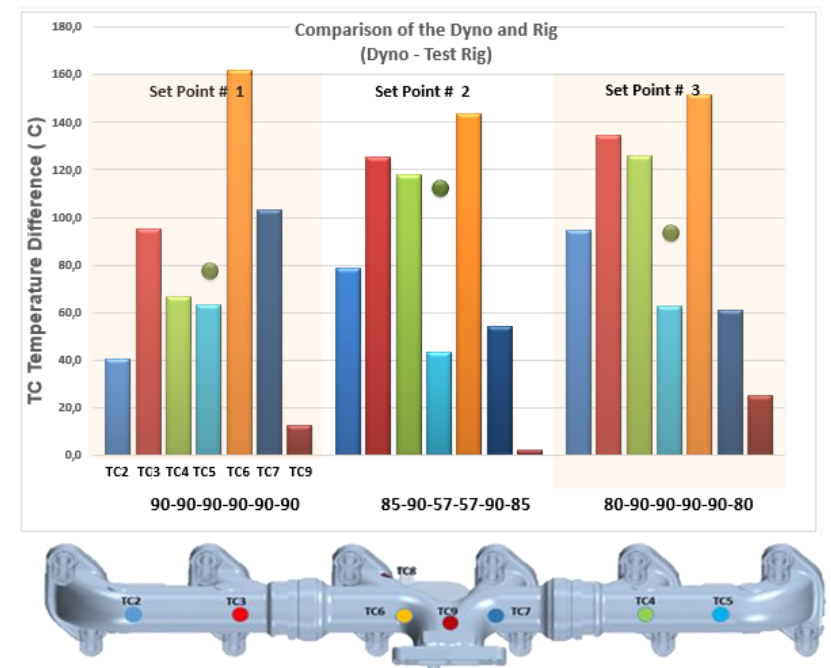

Figure 20. Effect of the EGR valve set by manual adjustment

CFD results show that the angles of the fourth valve set are the proposed methodology. The temperature measurements of valve set 4 have an excellent comparison with measurement results the two being within a $7 \%$ error.

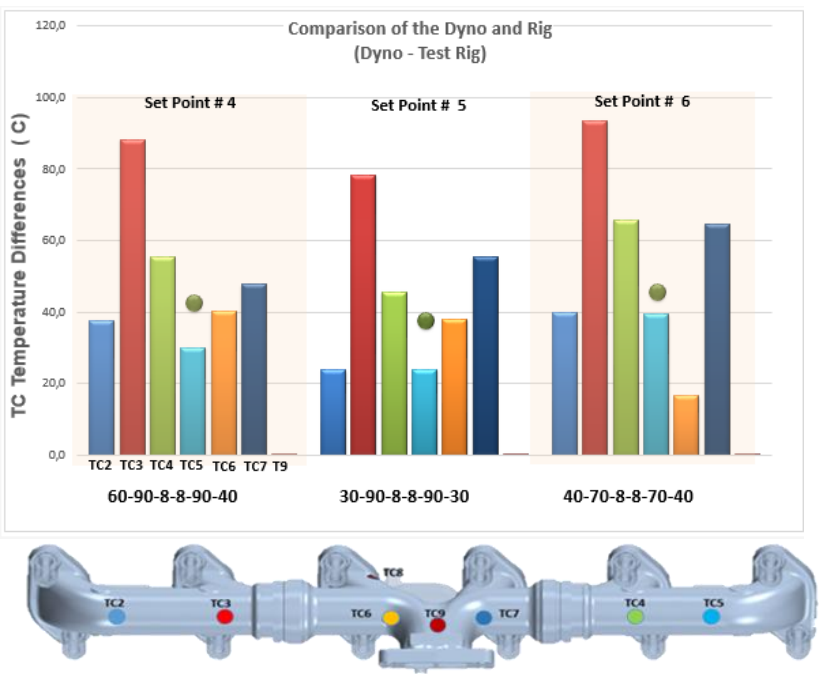

Figure 21. Effect of the EGR valve set by CFD adjustment

\section{CONCLUSION}

A custom-made exhaust manifold test rig was built, enabling the validation of exhaust manifold design and eliminating the need for long period dynamometer runs. This custom test rig can mimic the real-life exhaust manifold thermal loading. The temperature measurements obtained from the test rig run with steady flow showed consistent with engine dynamometer measurements results.

Obtaining similar thermal results from the test rig with a dynamometer requires an optimum valve setting for each runner, which is a challenging task. The trial and error approach (iterative method) to reach the optimum configuration for the valve sets requires a considerable effort and not an efficient way and may lead to a dead end.

In this study, the coupling of CFD/co-simulation and optimization tools enabling the process for determining each valve's optimum openings were proven very effective and efficient approach. Optimization algorithms embedded in Modefrontier lead to defining correct operating conditions and valve openings, resulting in a sufficiently accurate correlation for temperature distribution.

The following conclusions can be drawn from these studies:

- An iterative method to determine the valve angle settings for the accurate exhaust manifold thermal distribution took 16 test runs for this specific case for each operating condition. As can be seen from figure 19 , the temperature difference between the test rig and dynamometer decreased to \% 10 error with 16 runs for one operating condition. This is time consuming, inefficient, and expensive way to run for several different operating conditions.

- Valve set openings were optimized by the coupling of CFD and Modefrontier methodology efficiently. 
The valve angular position predictions proposed by this method end up with a $\% 7$ variation for the test result. The test rig under predicts the dynamometer temperature results.

- This study shows the very efficient and robust way of design verification of exhaust manifold in the custom-made test rig developed in-house. With the help of the CFD and optimization tool, the efficiency of running the rig improved significantly.

\section{ACKNOWLEDGMENTS}

The authors would like to acknowledge the support and activities of Aydin Ayyildiz and Hakan Gokoglu from Ford Otosan.

\section{REFERENCES}

Meda L., Shu Y. and Meda L., 2012, Exhaust System Manifold Development. SAE, 2012-01-0643.

Ångström H. and Fuchs L., 2009, A Comparative Study Between 1D and 3D Computational Results. SAE, 1112.

Annand W., 1963, Heat transfer in the cylinders of reciprocating internal combustion engines. Proc IMechE.

Assanis H., 1986, Development and use of a computer simulation of the turbo compounded diesel engine performance and component heat transfer studies. $S A E(860329)$.

Belingiardi G. and Leonti S. 1987, Modal Analysis in the design of an automotive exhaust pipe. International Journal Vehicle Design, 475-487.

Benoit M., 2012, Cyclic behavior of structures under thermomechanical loadings: application to exhaust manifolds. Int. J. Fatigue, 65-74.

Byung Kyu K., 2013, High-temperature low cycle fatigue properties of $24 \mathrm{Cr}$ ferritic stainless steel for SOFC applications. Materials Science and Engineering, 81-86.

Cartwright, J., Selamet, A., Wade, R., Miazgowicz, K. and Sloss, C., 2015, Heat Rejection and Skin Temperatures of an Externally Cooled Exhaust Manifold. SAE, 1736.

Celikten B., Duman I., Harman C. and Eroglu S., 2018, Exhaust Manifold Thermal Assessment with Ambient Heat Transfer Coefficient Optimization. SAE, 06-04.

Charkaluk E., Bignonnet A., Constantinescu A. and Dang Van K., 2002, Fatigue design of structures under thermomechanical loadings. Fatigue Fracture Engineering, 1119-1206.

Chen M., Wang Y., Wu W. and Xin, J., 2014, Design of the Exhaust Manifold of a Turbo Charged Gasoline
Engine Based on a Transient Thermal Mechanical Analysis Approach, SAE 01-2882.

Demirkesen C., Colak U., Savci I. and Zeren H., 2020, Experimental and Numerical Investigation of Air Flow Motion In Cylinder of Heavy Duty Diesel Engines. Journal of Applied Fluid Mechanics, 537-547.

Ekstrem J., 2014, High-temperature mechanical and fatigue properties of cast alloys intended for use in exhaust manifolds. Materials Science Engineering, 78-87.

European Parliament and Council, 2009, Emission Performance Standards for New Passenger Cars as part of the Community's Integrated Approach to Reduce CO2 Emissions from Light-Duty Vehicles. Regulation (EC) No. 443/2009.

Hasse C., Sohm V. and Durst B., 2010, Numerical investigation of cyclic variations in gasoline engines using a hybrid URANS/LES modeling approach. Computers \& Fluids, 25-48.

Heywood J.B., 1988, Internal Combustion Engine Fundamentals, McGraw-Hill Inc.

Ho H., 1972, Shakedown in elastic-plastic systems under dynamic loadings. J. Appl. Mech., 416-421.

Moeckel M., 1994, Computational Fluid Dynamic (CFD) Analysis of a Six-Cylinder Diesel Engine, SAE.

Rohsenow W., Hartnett J. and Cho Y., 1998, Handbook of Heat Transfer. New York, USA: McGraw-Hill Inc.

Savci I. and Zeren H., 2019, Deposit Testing in Exhaust Systems and Deposit Mapping Strategy. Journal of Thermal Science and Technology, 163-167.

Simone G., 2014, Low-Cycle Thermal Fatigue and HighCycle Vibration Fatigue Life Estimation of a Diesel Engine Exhaust Manifold. Procedia Engineering, 105 112.

STAR-CCM+., 2019, Version 13.04.011 User Manual > Simulating Physics $>$ Heat Transfer $>$ Convective Heat Transfer Coefficients > Guidelines for Heat Transfer Coefficients > Specified y+ Heat Transfer Coefficient. $S A E$.

Wolff K., Schneider M. and Schernus C., 1988, Computer-aided development of exhaust system durability. Global Powertrain Congress, 179-187.

Yanarocak R., Ergenc A. and Duman I., 2016, Thermal Analysis of Heavy Duty Engine Exhaust Manifold Using CFD. $S A E, 0648$. 
Zhien L., Wang X., Yan Z., Li X. and Xu Y. , 2014, Study on the Unsteady Heat Transfer of Engine Exhaust Manifold Based on the Analysis Method of Serial

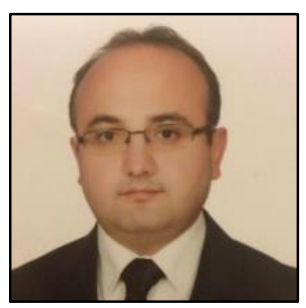

Ismail Hakki Savci was born in Erzurum Turkey in 1984. He got his MSc. and PhD. in 2009 and 2016. His current role is technical manager in Ford OTOSAN R\&D Center.

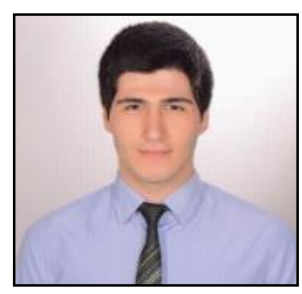

Baran Celikten was born in Adana Turkey in 1991. He is graduated from Istanbul Technical University Mechanical Engineering Department in 2014. He got his MSc. degree from the Mechanical Engineering Department of Istanbul Technical University (Turkey) in 2016. He is working as a Senior Product Development Engineer at Ford OTOSAN R\&D Center.

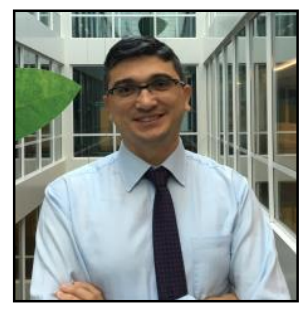

Sinan Eroglu was born in Eskisehir Turkey in 1979. He got his BSc. degree from the Mechanical Engineering Department of Middle East Technical University (Turkey) in 2002. Then he got his $\mathrm{PhD}$ degree from the Mechanical Engineering Department of Loughborough University (UK) in 2007. His current role is manager of Powertrain CAE department in Ford OTOSAN R\&D Center. 